\begin{tabular}{|c|c|}
\hline Journal STAND: Sports and Development \\
unipa Sunabaya & $\mathrm{http} / /$ jurnal.unipasby.ac.id/index.php/stand/about/submissions \\
\hline
\end{tabular}

\title{
Analisis Hasil Pertandingan Pencak Silat Pada Kejuaraan DANDIM CUP III Kabupaten Nganjuk Tahun 2019
}

\author{
Brahmana Rangga Prastyana ${ }^{1}$ \\ Fakultas Keguruan Dan Ilmu Pendidikan, Universitas PGRI Adi Buana Surabaya \\ brahmanarangga1988@gmail.com
}

\section{Artikel Info}

Koresponden penulis:

Brahmana Rangga $\mathrm{P}$

Email.

brahmanarangga1988@gmail.com

Diterima 8 Mei 2020

$\square$ Direview 12 Mei 2020

$\square$ Disetujui 12 Mei 2020

$\square$ Dipublikasi 27 Mei 2020

Kata Kunci:

Pengembangan Model Pembelajaran, Kerjasama tim, efektifitas penguasaan gerakan senam dasar prestasi

Keywords:

Analisis, Hasil Pertandingan, Pencak Silat, Kejuaraan DANDIM CUP III

\begin{abstract}
Abstrak
Hasil pertandingan selain sebagai dasar dalam pengembilan keputusan pemenang, juga sebagai bentuk informasi kepada pelatih dan atlet apakah teknik yang telah diberikan efektif dalam memperoleh nilai ketika bertanding. Dengan gerakan efektif dan efisien, maka dapat menghasilkan bentuk serangan yang maksimal sehingga mampu memperoleh nilai tertinggi. Selain itu, Hasil pertandingan dapat digunakan sebagai bahan evaluasi terhadap teknik yang paling dominan dalam menghasilkan nilai.

Peneliti ingin menganalisis hasil pertandingan pada Kejuaraan Pencak Silat Piala DANDIM CUP III Tahun 2019 Kabupaten Nganjuk. Melalui analisis yang dilakukan diharapkan mampu memberikan kontribusi dalam bentuk informasi data ilmiah kepada Atlet, Pelatih, dan Pengurus IPSI Kabupaten Nganjuk. Dengan banyaknya data dari berbagai aspek diharapkan dapat meningkatkan prestasi pencak silat di IPSI Kabupaten Nganjuk.

Berdasarkan serangkaian hasil penelitian dapat diambil kesimpulan bahwa: (1) Tidak semua kontingen mengirimkan atlet di tiap kelas yang dipertandingkan sehingga terdapat kelas yang kosong, seperti kelas J dan kelas Bebas, (2) skor pertandingan rata-rata yang sering muncul yaitu perolehan dengan angka 5 vs 0 dengan persentase $60 \%$, 4 vs 1 dengan persentase $14 \%, 3$ vs 2 dengan persentase sebesar $11 \%$. Selanjutnya sebesar $4 \%$ diskualifikasi, $8 \%$ undur diri, $2 \%$ kemenangan teknik, dan keputusan kemenangan akibat Wasit Menghentikan Pertandingan sebesar $1 \%$.
\end{abstract}

\begin{abstract}
The results of the match other than as a basis in winning the decision of winners, also as a form of information to coaches and athletes whether the techniques that have been given are effective in getting value when competing. With effective and efficient movements, it can produce the maximum form of attack so that it is able to obtain the highest value. In addition, match results can be used as an evaluation material for the most dominant technique in producing value.

The researcher wants to analyze the results of the match at the DANDI CUP III Cup Pencak Silat Championship in 2019 Nganjuk Regency. Through the analysis conducted it is expected to be able to contribute in the form of scientific data information to athletes, trainers and administrators of Nganjuk IPSI. With so many data from various aspects it is expected to improve the performance of martial arts in IPSI Nganjuk Regency.

Based on a series of research results it can be concluded that: (1) Not all contingents send athletes in each class that are contested so that there are empty classes, such as class $J$ and class Free, (2) average game scores that often appear are the acquisition with numbers 5 vs 0 with a percentage of $60 \%, 4$ vs 1 with a percentage of $14 \%, 3$ vs 2 with a percentage of $11 \%$. Furthermore, by $4 \%$ disqualification, $8 \%$ withdrawal, $2 \%$ technical victory, and the decision of victory due to Referee Stopping the Match by $1 \%$.
\end{abstract}




\begin{tabular}{|c|c|c|}
\hline Unipa Sumabaya & $\begin{array}{c}\text { Journal STAND: Sports and Development } \\
\text { http://jurnal.unipasby.ac.id/index.php/stand/about/submissions } \\
\text { jurnal.stand@unipasby.ac.id }\end{array}$ & 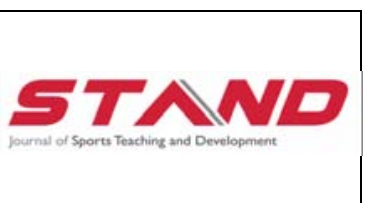 \\
\hline
\end{tabular}

\section{A. PENDAHULUAN}

Salah satu warisan pendahulu bangsa Indonesia yang telah mendunia yaitu pencak silat. Tidak hanya sebagai tradisi, pencak silat kini menjadi cabang olahraga yang semakin banyak diminati oleh kaum milenial. Pencak silat sebagai tradisi memiliki berbagai istilah dibeberapa daerah. Sumatera Brat menyebut pencak silat dengan istilah silek/gayung, Sumatra Barat menyebut dengan istilah bersilat, Jawa Tengah, Jawa Timur, Yogyakarta dengan istilah pencak, Madura dan Bawean dengan Mancak (Kriswanto, E.S, 2015:13).

Ikatan Pencak Silat Indonesia (IPSI) menjabarkan pencak silat merupakan serangkaian gerak bela seran yang teratur menurut sistem, waktu, tempat, dan iklim dengan selalu menjaga kehormatan masingmasing secara kesatria, tidak mau melukai perasaan, sedangkan silat merupakan gerak bela serang yang erat hubungannya dengan rohani, sehinga menghidup suburkan naluri, menggerakkan hati nurani manusia, langsung menyerah pada Tuhan Yang Maha Esa (Mariono, 2000: 05).

Pencak silat merupakan cabang olahraga yang telah banyak dipertandingan dari tingkat Kabupaten hingga Internasional. Pertandingan pencak silat diselenggarakan dalam rangka mencari bibit atlet. Selain itu, pertandingan pencak silat dilaksanakan untuk memberikan wadah bagi para atlet agar dapat menunjukkan perkembangan yang telah dijalani selama proses latihan. Tanpa adanya pertandingan maka seorang atlet tidak dapat mengasah keterampilan secara langsung.

Pertandingan pencak silat di laksanakan meliputi beberapa golongan, dari mulai usia dini hingga golongan usia dewasa. Pertandingan pencak silat memiliki aturan yang telah ditetapkan oleh IPSI (Ikatan Pencak Silat Indonesia) dalam lingkup nasional. Pada lingkup Internasional, peraturan pertandingan pencak silat ditetapkan oleh PERSILAT. Dalam pertandingan pencak silat, terdapat beberapa kategori mulai dari kategori tanding dan kategori seni. Kategori tanding terdiri dari beberapa kelas yang dibedakan menurut berat badan, sedangkan pada kategori seni terdiri dari seni tunggal, ganda, dan regu.

Mengutip dari Peraturan Pertandingan Ikatan Pencak Silat Indonesia (2012), kategori tanding menampilkan 2 (dua) orang pesilat dari sudut merah dan sudut biru. Kedua pesilat dari sudut merah dan biru saling berhadapan dengan menggunakan unsur pembelaan dan serangan serta kaidah-kaidah pencak silat. Kategori Tunggal menampilkan kemahiran jurus Tunggal baku seccara benar, tepat dan mantap, penh penjiwaan dengantangan kosong maupun senjata, serta tunduk pada ketentuan dan peraturan yang berlaku dalam kategori ini. Selanjutnya, kategori Ganda, yaitu menampilkan dua orang pesilat dari tim yang sama untuk memperagakan kemahiran dan kekayaan jurus serang bela yang dimiliki secara terencana, efektif, estetis, mantap dan logis. Berikutnya 


\begin{tabular}{|c|c|c|}
\hline Journal STAND: Sports and Development & http://jurnal.unipasby.ac.id/index.php/stand/about/submissions \\
unipa Smalanga & jurnal.stand@unipasby.ac.id
\end{tabular}

yaitu kategori Regu. Kategori ini menampilkan 3

(tiga) orang pesilat dari tim yang sama untuk memperagakan kemahiran dalam jurus Regu baku secara benar, tepat, mantap, penuh penjiwaan dan kompak serta tunguk pada ketentuan yang berlaku.

Di Indonesia, pertandingan diselenggarakan hampir di seluruh Provinsi. Tiap-tiap Provinsi menyelenggarakan dalam berbagai jenis event, mulai dari Pekan Olahraga Provinsi, O2SN, POPDA atau kejuaraan yang bersifat singgle event. Kejuaraan tersebut diselenggarakan tidak hanya lingkup Provinsi, akan tetapi juga di lingkup Kabupaten.

Salah satu Kabupaten di Jawa Timur yang aktif menyelenggarakan event kejuaraan yaitu Kabupaten Nganjuk. Program Kerja Pengurus Ikatan Pencak Silat Indonesia (IPSI) Kabupaten Nganjuk pada tahun 2019 yaitu menyelenggarakan kejuaraan pencak silat piala DANDIM CUP. Kejuaraan DANDIM CUP telah diselenggarakan selama 3 (tiga) tahun berturut-turut. Pada tahun 2019, kejuaraan ini diselenggarakan dengan melibatkan seluruh Kecamatan yang ada di Kabupaten Nganjuk sebagai perserta.

Mengutip dari Proposal Kejuaraan DANDIM CUP 2019 Kabupaten Nganjuk diselenggarakan dalam rangka mencari bibit atlet untuk dibina dan mewakili kabupaten Nganjuk pada kejuaraan di lingkup Provinsi. Selain itu, dengan adanya pertandingan ini, diharapkan dapat memberikan rangsangan pada pelatih-pelatih yang berada di IPSI Kecamatan untuk selalu membina atletnya.

Sebagai bentuk usaha dalam meningkatkan prestasi pencak silat di Kabupaten Nganjuk melalui kejuaraan yang diselenggarakan, perlu melakukan suatu kajian dari hasil pertandingan yang telah dilaksanakan. Kajian secara ilmiah diperlukan untuk memperoleh suatu informasi apakah kejuaraan pencak silat DANDIM CUP 2019 sesuai dengan tujuan. Analisis dilakukan tidak hanya untuk memperbaiki pelaksanaan, akan tetapi juga dibutuhkan untuk mengetahui sebaran atlet yang mengikuti pada tiap kelas yang dipertandingkan.

Informasi lain yang tidak kalah pentingnya yaitu terkait dengan skor pertandingan dari tiap atlet yang bertanding. Skor yang diperoleh dalam tiap kali pertandinggan menunjukkan kualitas pembinaan yang telah dilakukan di lingkup kecamatan. Misalnya, dalam satu kali pertanding pada tiap kelas diperoleh skor 5 (lima) banding 0 (enol). Perolehan sekor tersebut menunjukkan perbedaan kualitas antara kedua pesilat yang begitu jauh. Kondisi tersebut dapat diasumsikan apakah ada perbedaan secara kualitas dari kedua atlet tersebut atau terdapat faktor lain yang menyebabkan perbedaan skor begitu jauh.

Hasil pertandingan selain sebagai dasar dalam pengembilan keputusan pemenang, juga sebagai bentuk informasi kepada pelatih dan atlet apakah teknik yang telah diberikan efektif dalam memperoleh nilai ketika bertanding. Dengan gerakan efektif dan efisien, maka dapat 


\begin{tabular}{|c|c|}
\hline Journal STAND: Sports and Development \\
unipa Suralaya & $\mathrm{http} / /$ jurnal.unipasby.ac.id/index.php/stand/about/submissions \\
\hline
\end{tabular}

menghasilkan bentuk serangan yang maksimal sehingga mampu memperoleh nilai tertinggi. Selain itu, Hasil pertandingan dapat digunakan sebagai bahan evaluasi terhadap teknik yang paling dominan dalam menghasilkan nilai.

Hasil penelitian yang telah dilakukan oleh Dilami dan Tutur (2019: 12) pada Kejuaraan Pencak Silat Se-Jawa Timur Open Piaa Rektor UNESA tahun 2018 menunjukkan bahwa dari semua teknik yang dilakukan, tendangan sabit paling banyak dilakukan dengan persentase $39,05 \%$. Hal itu menujukkan bahwa tendangan sabit dominan dilakukan untuk memperoleh nilai. Tanpa adanya data hasil pertandingan maka akan sulit melakukan evaluasi terhadap keberhasil teknik atlet dalam memperoleh nilai.

Berpijak dari uraian yang telah dijelaskan, maka peneliti ingin menganalisis hasil pertandingan pada Kejuaraan Pencak Silat Piala DANDIM CUP III Tahun 2019 Kabupaten Nganjuk. Melalui analisis yang dilakukan diharapkan mampu memberikan kontribusi dalam bentuk informasi data ilmiah kepada Atlet, Pelatih, dan Pengurus IPSI Kabupaten Nganjuk. Dengan banyaknya data dari berbagai aspek diharapkan dapat meningkatkan prestasi pencak silat di IPSI Kabupaten Nganjuk.

\section{B. METODE PENELITIAN}

Penelitian ini menggunakan pendekatan kuantitatif deskriptif. Dimana penelitian ini berusaha menggambarkan fenomena dari fakta yang telah diperoleh secara terperinci. Tujuan utama penelitian ini yaitu untuk menggambarkan kondisi atau keadaan terkait variabel. Artinya bahwa dalam penelitian ini peneliti berusaha menggambarkan melalui seangkaian analisis terkait dengan hasil pertandingan Kejuaraan DANDIM CUP III Kabupaten Nganjuk Tahun 2019.

Selanjutnya agar tidak terjadi kesalahan dalam variabel penelitian, diperlukan definisi operasional. Variabel merupakan segala sesuatu yang berbentuk apa saja dan telah ditetapkan oleh peneliti untuk dikaji sehingga memperoleh suatu informasi untuk diambil kesimpulan (Sugiono, 2009:60). Variabel dalam penelitian ini yaitu hasil akhir pertandingan yaitu perolehan skor atlet ketika bertanding dari awal penyisihan hingga final.

Populasi dan sampel penelitian dalam hal ini yaitu keseluruhan atlet yang bertanding di Kejuaraan DANDIM CUP III Kabupaten Nganjuk Tahun 2019. Sehigga dapat dikatan bahwa penelitian ini termasuk dalam kategori penelitian populasi. Sedangkan teknik pengumpulan data yaitu dengan menggunakan dokumen hasil pertandingan yang diperoleh dari sekertaris pertandingan pada Kejuaraan Pencak Silat Piala DANDIM CUP III Tahun 2019. Setelah memperoleh data, maka kegiatan selanjutnya yaitu melakukan analisis untuk mendapatkan informasi. Dalam penelitian ini data dianalisis menggunakan teknik statistik deskriptif dan distribusi frequensi. 


\begin{tabular}{|c|c|}
\hline Journal STAND: Sports and Development & http://jurnal.unipasby.ac.id/index.php/stand/about/submissions \\
unipa Sumalayg & jurnal.stand@unipasby.ac.id
\end{tabular}

\section{HASIL PENELITIAN}

\section{Analisis Data}

Serangkaian kegiatan dalam pengumpulan data yang telah dilakuan terkait hasil pertandingan Kejuaraan DANDIM CUP III Kabupaten Nganjuk Tahun 2019. Kegiatan kejuaraan dilaksanakan pada tanggal 27 sampai tanggal 29 Oktober tahun 2019. Jumlah atlet yang mengikuti sebanyak 190 atlet terdiri dari 127 atlet putra dan 63 atlet putri. Total keseluruhan kontingem sebanyak 20 kontingen. Secara rinci dapat dilihat di tabel jumlah peserta pada tiap kelas berikut

Tabel. Jumlah Peserta Pada Tiap Kelas

\begin{tabular}{c|c|c|c}
\hline \multicolumn{2}{c|}{ Putra } & \multicolumn{2}{c}{ Putri } \\
\hline Kelas & Peserta & Kelas & Peserta \\
\hline A & 14 & A & 14 \\
\hline B & 17 & B & 10 \\
\hline C & 17 & C & 12 \\
\hline D & 18 & D & 6 \\
\hline E & 16 & E & 8 \\
\hline F & 16 & F & 6 \\
\hline G & 12 & G & 3 \\
\hline H & 9 & H & 4 \\
\hline I & 8 & & \\
\hline J & 0 & & \\
\hline BEBAS & 0 & & \\
\hline Total & 127 & & 63 \\
\hline
\end{tabular}

Berdasarkan tabel di atas menunjukkan bahwa terdapat kelas yang kosong atau tidak ada peserta yaitu kelas $\mathrm{J}$ dan Kelas Bebas putra. Berikutnya dari jumlah peserta tersebut terdapat 173 partai pertandingan dengan rincian seperti pada tabel berikut.

Tabel Jumlah Partai Pertandingan

\begin{tabular}{l|c}
\hline Partai & Partai Pertandingan \\
\hline Penyisihan & 4 \\
\hline 1/8 Final & 63 \\
\hline 1/4 Final & 56 \\
\hline Semi Final & 33 \\
\hline Final & 17 \\
\hline Total & 173 \\
\hline
\end{tabular}

Selanjutnya, ditampilkan hasil distribusi frekuensi hasil pertandingan sesuai dengan keputusan kemenangan berdasarkan Angka, diskualifikasi (DIS), Undur Diri (UD), kemenangan Teknik (TK), dan keputusan kemenangan akibat Wasit Menghentikan Pertandingan (WMP).

Tabel Hasil Pertandingan

\begin{tabular}{|c|c|c|c|c|c|c|c|c|}
\hline \multirow{2}{*}{\multicolumn{2}{|c|}{$\begin{array}{l}\text { Kelas } \\
\text { Pesilat }\end{array}$}} & \multicolumn{7}{|c|}{$\begin{array}{c}\text { Skor Kemenangan } \\
\text { Pertandingan }\end{array}$} \\
\hline & & 5 & 4 & $\mathbf{3}$ & D & $\mathbf{U}$ & $\mathbf{T}$ & W \\
\hline \multirow{9}{*}{ こ } & A & 9 & 1 & 1 & 0 & 0 & 2 & 0 \\
\hline & B & 9 & 1 & 3 & 0 & 3 & 0 & 0 \\
\hline & C & $\begin{array}{l}1 \\
0\end{array}$ & 2 & 1 & 1 & 1 & 1 & 0 \\
\hline & D & $\begin{array}{l}1 \\
0\end{array}$ & 3 & 2 & 1 & 1 & 0 & 0 \\
\hline & $\mathrm{E}$ & 8 & 4 & 1 & 0 & 2 & 0 & 0 \\
\hline & $\mathrm{F}$ & $\begin{array}{l}1 \\
1\end{array}$ & 1 & 1 & 1 & 1 & 0 & 0 \\
\hline & $\mathrm{G}$ & 8 & 2 & 0 & 0 & 1 & 0 & 0 \\
\hline & $\mathrm{H}$ & 4 & 2 & 2 & 0 & 0 & 0 & 0 \\
\hline & $\mathrm{I}$ & 3 & 2 & 0 & 2 & 0 & 0 & 0 \\
\hline \multirow{8}{*}{ 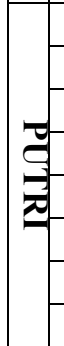 } & A & 7 & 1 & 2 & 1 & 2 & 0 & 0 \\
\hline & B & 3 & 1 & 2 & 1 & 0 & 0 & 2 \\
\hline & $\mathrm{C}$ & 8 & 1 & 1 & 0 & 1 & 0 & 0 \\
\hline & D & 2 & 2 & 0 & 0 & 0 & 1 & 0 \\
\hline & $\mathrm{E}$ & 6 & 1 & 0 & 0 & 0 & 0 & 0 \\
\hline & $\mathrm{F}$ & 5 & 0 & 0 & 0 & 0 & 0 & 0 \\
\hline & $\mathrm{G}$ & 0 & 0 & 1 & 0 & 1 & 0 & 0 \\
\hline & $\mathrm{H}$ & 0 & 0 & 2 & 0 & 1 & 0 & 0 \\
\hline
\end{tabular}

Berdasarkan data tabel hasil pertandingan, ditampilkan pula nilai rata-rata dan persentase. Berikut rata-rata dan persentase hasil pertandingan dan persentase tiap kelas kategori tanding. 


\begin{tabular}{|c|c|}
\hline Journal STAND: Sports and Development \\
unipa Sumalaya & $\mathrm{http} / /$ jurnal.unipasby.ac.id/index.php/stand/about/submissions \\
\hline
\end{tabular}

Tabel mean dan \% Skor

\begin{tabular}{c|c|c}
\hline $\begin{array}{l}\text { Skor Kemenangan } \\
\text { Pertandingan }\end{array}$ & Mean & $\%$ \\
\hline 5 vs 0 & 6 & 60 \\
\hline 4 vs 1 & 1 & 14 \\
\hline 3 vs 2 & 1 & 11 \\
\hline DIS & 0 & 4 \\
\hline UD & 1 & 8 \\
\hline TK & 0 & 2 \\
\hline WMP & 0 & 1 \\
\hline
\end{tabular}

Tabel Persentase tiap Kelas kategori

\begin{tabular}{|c|c|c|c|c|c|c|c|c|}
\hline \multirow{2}{*}{\multicolumn{2}{|c|}{\begin{tabular}{|c} 
Kela \\
s
\end{tabular}}} & \multicolumn{7}{|c|}{$\begin{array}{c}\text { Persentase (\%) Skor } \\
\text { Kemenangan Pertandingan }\end{array}$} \\
\hline & & $\begin{array}{c}5 \\
\text { vs } \\
\text { 0 }\end{array}$ & $\begin{array}{c}4 \\
\text { vs } \\
1\end{array}$ & $\begin{array}{c}3 \\
\text { vs } \\
2\end{array}$ & $\begin{array}{l}\text { D } \\
\text { I } \\
\text { S }\end{array}$ & $\begin{array}{l}\text { U } \\
\mathbf{D}\end{array}$ & $\begin{array}{l}\mathbf{T} \\
\mathbf{K}\end{array}$ & $\begin{array}{c}\mathbf{W} \\
\mathbf{M} \\
\mathbf{P}\end{array}$ \\
\hline \multirow{9}{*}{ 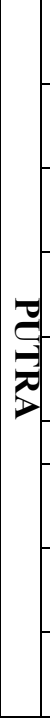 } & A & 69 & 8 & 8 & 0 & 0 & $\begin{array}{l}1 \\
5\end{array}$ & 0 \\
\hline & B & 56 & 6 & $\begin{array}{l}1 \\
9\end{array}$ & 0 & $\begin{array}{l}1 \\
9\end{array}$ & 0 & 0 \\
\hline & $\mathrm{C}$ & 63 & $\begin{array}{l}1 \\
3\end{array}$ & 6 & 6 & 6 & 6 & 0 \\
\hline & D & 59 & $\begin{array}{l}1 \\
8\end{array}$ & $\begin{array}{l}1 \\
2\end{array}$ & 6 & 6 & 0 & 0 \\
\hline & E & 53 & $\begin{array}{l}2 \\
7\end{array}$ & 7 & 0 & $\begin{array}{l}1 \\
3\end{array}$ & 0 & 0 \\
\hline & $\mathrm{F}$ & 73 & 7 & 7 & 7 & 7 & 0 & 0 \\
\hline & G & 73 & $\begin{array}{l}1 \\
8\end{array}$ & 0 & 0 & 9 & 0 & 0 \\
\hline & $\mathrm{H}$ & 50 & $\begin{array}{l}2 \\
5\end{array}$ & $\begin{array}{l}2 \\
5\end{array}$ & 0 & 0 & 0 & 0 \\
\hline & I & 43 & $\begin{array}{l}2 \\
9\end{array}$ & 0 & $\begin{array}{l}2 \\
9 \\
\end{array}$ & 0 & 0 & 0 \\
\hline \multirow{8}{*}{ 를 } & A & 54 & 8 & $\begin{array}{l}1 \\
5\end{array}$ & 8 & $\begin{array}{l}1 \\
5\end{array}$ & 0 & 0 \\
\hline & B & 33 & $\begin{array}{l}1 \\
1\end{array}$ & $\begin{array}{l}2 \\
2\end{array}$ & $\begin{array}{l}1 \\
1\end{array}$ & 0 & 0 & $\begin{array}{l}2 \\
2\end{array}$ \\
\hline & $\mathrm{C}$ & 73 & 9 & 9 & 0 & 9 & 0 & 0 \\
\hline & D & 40 & $\begin{array}{l}4 \\
0\end{array}$ & 0 & 0 & 0 & $\begin{array}{l}2 \\
0\end{array}$ & 0 \\
\hline & $\mathrm{E}$ & 86 & $\begin{array}{l}1 \\
4\end{array}$ & 0 & 0 & 0 & 0 & 0 \\
\hline & $\mathrm{F}$ & 100 & 0 & 0 & 0 & 0 & 0 & 0 \\
\hline & G & 0 & 0 & $\begin{array}{l}5 \\
0\end{array}$ & 0 & $\begin{array}{l}5 \\
0\end{array}$ & 0 & 0 \\
\hline & $\mathrm{H}$ & 0 & 0 & $\begin{array}{l}6 \\
7\end{array}$ & 0 & $\begin{array}{l}3 \\
3\end{array}$ & 0 & 0 \\
\hline
\end{tabular}

Berdasarkan tabel di atas, rata-rata skor kemenangan yang sering muncul yaitu perolehan dengan angka 5 vs 0 dengan persentase $60 \%, 4$ vs 1 dengan persentase $14 \%, 3$ vs 2 dengan persentase sebesar $11 \%$. Selanjutnya sebesar $4 \%$ diskualifikasi, $8 \%$ undur diri, $2 \%$ kemenangan teknik, dan keputusan kemenangan akibat Wasit Menghentikan Pertandingan sebesar 1\%.

\section{PEMBAHASAN}

Setelah dilakukan analisis data, peneliti melakukan pembahasan terkait hasil pertandingan pada kejuaraan DANDIM CUP III Kabupaten Nganjuk Tahun 2019. Kegiatan kejuaraan dilaksanakan pada tanggal 27 sampai tanggal 29 Oktober tahun 2019. Jika diamati berdasarkan jumlah perserta, terdapat peningkatan dari tahun sebelumnya yaitu hanya 158 meningkat menjadi 190. Total peserta terbagi antara atlet putra dan putri. Selain itu, tidak semua kontingen mengirimkan full team, artinya tidak hanya kela $\mathrm{J}$ dan Bebas yang tidak dimiliki oleh bebera kontingen akan tetapi terdapat kelas-kelas lain yang kontingen tersebut jugak tidak mengirimkan. Dari keseluruhan, terdapat kelas yang tidak ada peserta yaitu kelas J dan Bebas Putra. Hal ini menunjukkan bahwa tidak ada kontingen yang memiliki atlet di kelas tersebut. Dengan begitu maka, perlu mencari bibit atlet dengan berat badan yang sesuai pada kelas tersebut untuk dilakukan pembinaan. Selain itu, dengan melihat sedikitnya jumlah peserta pada kelas $\mathrm{J}$ dan Bebas, pelatih dapat 


\begin{tabular}{|c|c|}
\hline Journal STAND: Sports and Development \\
unipa Suralaya & $\mathrm{http} / /$ jurnal.unipasby.ac.id/index.php/stand/about/submissions \\
\hline
\end{tabular}

mengambil peluang untuk mendapatkan point medali jika ingin memperoleh juara umum.

Gambaran lain berdasarkan hasil analisi data tersebut yaitu terkait dengan hasil skor pertandingan. Secara keseluruhan, persentase kemenangan tertinggi diperoleh dengan angka yaitu nilai 5-0. Skor tersebut menunjukkan adanya perbedaan kemampuan. Perbedaan kemampuan dari segi fisik, tektik, tatik, atau mental. Perbedaan perolehan skor tersebut disebabkan karena pesilat yang baru mengikuti pertandingan mendapatkan lawan yang telah sering ikut pertandingan.

Selanjutnya kita amati pula terhadap adanya kemenangan yang diperoleh atlet dengan hasil Undur Diri (UD). Hasil tersebut perlu mendapat perhatian bagi seorang pelatih. Pelatih harus peka dan segera merespon jika hal itu terjadi. Undur diri dapat dikarenakan atlet cidera sebelum atau pada saat pertandingan. Faktor lain Undur diri dikarenakan pesilat tidak datang ketika telah dipanggil sebanyak 3 kali. Jika telah dipanggil selama 3 kali tidak datang ke gelanggang pertandingan maka dianggap undur diri.

Pada pertandingan di Kejuaraan DANDIM CUP III Kabupaten Nganjuk Tahun 2019, undur diri pesilat diakibatkan karena adanya cidera yang dialami oleh atlet akibat cidera yang diperoleh ketika dia bertandingan pada partai sebelumnya. Itu menunjukkan bahwa, penting bagi pelatih mengontrol melalui instruksi ketika atlet bertanding, mengingat atlet yang bertanding rata-rata pemula. Memberikan pengertian sekaligus ajang memberikan wawasan bagaimana mencari dan memperoleh point dengan aman, efektif, dan efisien sehingga dapat bertanding sampai babak final. Kontrol emosional juga ditanamkan pada atlet dalam bertandiang sehingga dalam melakukan serangan tidak hanya emosi yang muncul, namun fokus pada bagaimana mencari peluang untuk memperoleh nilai. Pelatih juga seharusnya cepat tanggap ketika melihat atlet mengalami cidera sehingga tidak memaksakan diri untuk melanjutkan pertandingan, mengingat mereka masih dalam level pemula, masih banyak pertandingan yang bisa diikuti dalam rangka mencari prestasi.

\section{E. SIMPULAN}

Berdasarkan serangkaian hasil penelitian dapat diambil kesimpulan bahwa: (1) Tidak semua kontingen mengirimkan atlet di tiap kelas yang dipertandingkan sehingga terdapat kelas yang kosong, seperti kelas J dan kelas Bebas, (2) skor pertandingan rata-rata yang sering muncul yaitu perolehan dengan angka 5 vs 0 dengan persentase $60 \%$, 4 vs 1 dengan persentase $14 \%$, 3 vs 2 dengan persentase sebesar $11 \%$. Selanjutnya sebesar $4 \%$ diskualifikasi, $8 \%$ undur diri, 2\% kemenangan teknik, dan keputusan kemenangan akibat Wasit Menghentikan Pertandingan sebesar $1 \%$.

\section{SARAN}

Berpijak pada hasi peneitian maka disarankan perlu untuk mencari bibit-bibit atlet untuk dapat mengisi kelas-kelas yang dipertandingan sehingga kontingen dapat 


\begin{tabular}{|c|c|}
\hline Journal STAND: Sports and Development \\
unipa Sumalanya & http://jurnal.unipasby.ac.id/index.php/stand/about/submissions \\
\hline
\end{tabular}

berpeluang untuk memperoleh juara umum.

Selain itu, pelatih perlu mempertimbangkan apakah atletnya layak untuk diikut sertakan dalam suatu kejuaraan entah dimanapun levelnya. Pelatih harus tanggap dan merespon ketika terjadi cidera dalam pertandingan sehingga atlet lekas mendapatkan penanganan. Untuk panitia penyelenggara selanjutnya perlu menambah nomor pertangingan yaitu kategori Tunggal, Ganda, dan Regu. Bagi peneliti lain, dapat melanjukan dan fokus pada analisis pelaksanaan secara keseluruhan hasil pertandingan meliputi kepanitiaan serta kualitas wasit dan juri pada pertandingan pencak silat.

\section{F. DAFTAR PUSTAKA}

Dailami, M. Jatmiko, T. (2019). Analisis Statistik Teknik Tendangan Kategori tanding Kelas D Putra Mahasiswa Pada Kejuaraan Pencak Silat Se-Jawa Timur Open Piala Rektor UNESA Ke I 2018. Jurnal Prestasi Olahraga Vol 2 NO 3.https://jurnalmahasiswa.unesa.ac.id/index. php/jurnal-prestasiolahraga/article/view/30485.

Ikatan Pencak Silat Indonesia. (2012). Anggaran Dasar Anggaran Rumah Tangga. Surabaya. PENGPROV IPSI JAWA TIMUR.

Kriswanto, Erwin. S. (2015). Pencak Silat. Sejarah dan Perkembangan Pencak Silat Pengetahuan Dasar Pertandingan Pencak Silat. Pustaka Baru Press. Yogyakarta.

Mariono, O. (2000). Pencak Silat Merentang Waktu. Cet. Kedua. Yogyakarta. Yayasan Galang.

Sugiyono, 2009, Metode Penelitian Kuantitatif, Kualitatifdan R\&D, Bandung: Alfabeta 